Pivot is published through Open Journal Systems (OJS) at York University

(1)

Abstract: This paper examines the blending of Nigerian magical elements with science fiction in the writings of Nnedi Okorafor. Looking at her novels What Sunny Saw in the

Flames (2011) and

Lagoon (2014), we

examine the

juxtaposition of

traditional magical

elements with

science fictional

materials, which

leads to the

convergence of

pseudo-realistic

visions in her

narratives. This

\title{
Afro-Science Fiction: A Study of Nnedi Okorafor's What Sunny Saw in the Flames and Lagoon
}

paper analyses

Okorafor's novels in

the context of the novelty of science fiction in Nigerian literature. Particular attention is paid to the distinctive qualities of her artistry that locates her writing within a Nigerian framework as well as within a broader global science fiction culture.

\author{
Mary Bosede Aiyetoro and \\ Elizabeth Olubukola Olaoye
}

\section{(1)}

Both What Sunny Saw in the Flames (2011) and Lagoon (2014), authored by Nnedi Okorafor, display elements of magic and science fiction in their contents. In What Sunny Saw in the Flames, Okorafor tells the coming-of-age story of an albino girl who discovers her ancestral magical powers in contemporary Nigeria and struggles to find ways of coping with a magical cult in a modern society. Lagoon, on the other hand, introduces a novelty into the Nigerian literary canon by not only creating a magical world but also re-envisioning Lagos, Nigeria's commercial capital, under alien invasion; the novel marks a completely new turn in the history of Nigerian fiction and can be described as full-fledged Nigerian science fiction. 
In an observation that purports to capture the raison d'être of science fiction, Frederic Jameson contends that "the moment in which the historical novel as a genre ceases to be functional . . . is also the moment of the emergence of [science fiction] . . . as a form which ... registers some nascent sense of the future . . . in the space on which a sense of the past had once been inscribed" (qtd. in Milner 393). Although Jameson's contention is a rumination on western literature, it throws light on the emergence of science fiction as a genre. In other words, loss of confidence in the retelling of the past, in history, begets a longing for the future represented by such narrative modes as science fiction. While this may be true of much science fiction originating in the west, the same cannot be said in relation to the emergence of science fiction in Nigeria. There is no doubt that the science fiction genre is a novelty in Nigerian literature, and the publication dates of the two novels under study here confirm this: What Sunny Saw in the Flames and Lagoon were published in 2011 and 2014 respectively, yet only Lagoon can be described as a full-fledged science fiction novel.

Deidre Byrne accounts for a similar scarcity of science fiction in South Africa, noting that "the restricted degree of knowledge about technology in my country is largely responsible for the regrettable dearth here of published science fiction and science fiction readers. The supply-demand cycle of commodities further hobbles the wouldbe science fiction reader: with little demand for works of science fiction, bookshops wanting to make a profit place small orders; in turn there is less on the shelves for fans to buy" (522). What is true for 
science fiction in South Africa can also be said of Nigeria. The idea of a Nigerian science fiction is relatively new, as the genre is still bourgeoning in the country. Authors like Adebayo Williams, Biyi Bandele Thomas, and Ben Okri have transgressed the shores of realism in their narratives by experimenting with magical and pseudorealism in their work, but no writer has dared to engage with the idea of science fiction in Nigerian literature in that way that Okorafor has. The reasons for the genre's late arrival to the scene of Nigerian literature, however, are not necessarily the same as those identified by Byrne in the context of South African literature. While the restricted degree of technological knowledge in Nigeria, coupled with a market not yet tested with regards to science fiction, might be responsible, Okorafor herself has this to say about the late coming of genre: "I think Africans have loved the genre of science fiction for as long as the movies have been making their way to there. I think people are just not used to the stories in novel form because it hasn't been done before, not consciously. That's changing, so attitudes will change" (qtd. in Onifade). This is a hopeful statement by an author who believes that, if Africans embrace science fiction, there will be "an increase in imagination, a greater tolerance for and a greater interest in ideas, spiritualties, religions, people who are unlike the norm, greater social awareness, more worldly individuals and new and innovative technologies born from within the continent" (qtd. in Onifade).

Beyond this optimism for a change in cultural sensibilities, however, it should be noted that the story of the past is still a very 
active tool in interpreting the present in Nigerian literature. Since Chinua Achebe's popular statement, in his essay "The Novelist as a Teacher," that his stories are meant to correct negative impressions about the past (30), many Nigerian writers have revalidated the need to turn to the past in order to comprehend the present and to prepare for the future. Achebe clearly perceives storytelling as very important to both Nigerians and Africans in general. In his fifth novel, Anthills of the Savannah, a wise old man draws attention to the importance of storytelling in African communities:

it is only the story that can continue beyond the war and the warrior. It is the story that outlives the sound of war drums and the exploits of brave fighters. It is the story, not the others, that saves our progeny from blundering like blind beggars into the spikes of the cactus fence. The story is our escort; without it, we are blind. Does the blind man own his escort? No, neither do we, the story; rather it is the story that owns us and directs us. (124)

If stories are this important, as Achebe's fictional character in Anthills of the Savannah insists, it would matter less whether those stories focus on the past or on the future than that they affect us. In a 2009 TED talk, Nigerian writer Chimamanda Ngozi Adichie too, while highlighting the danger of a single story, saliently draws attention to the importance of stories to Africans:

I've always felt that it is impossible to engage properly with a place or a person without engaging with all of the stories of that place and that person ... Stories matter. Many stories 
matter. Stories have been used to dispossess and to malign. But stories can also be used to empower, and to humanize. Stories can break the dignity of a people. But stories can also repair that broken dignity . . . When we reject the single story, when we realize that there is never a single story about any place, we regain a kind of paradise.

Adichie's point is that human beings are impressionable and vulnerable in the face of stories and that storytelling is a form of power. Stories, in other words, make us who we are. Viewed narrowly, her statement might imply that stories in themselves can bestow identity, but her point is that, through stories and their telling, certain identities can be created or reinforced. In this connection, particular genres of fiction can be examined to see how each affects identity formulation and reinforcement. Science fiction is examined here to appraise its usefulness to Nigerian literature. Since the genre of science fiction is a relative novelty in Nigeria, its non-futuristic antecedents - in fantastic modes like folklore and magical realism are examined first. Addressing this means tracing the origins of the fantastic mode in Nigerian literature.

The presence of fantastic elements in Nigerian literature dates back to when written literature began flourishing in the country. From the mid-twentieth century, especially in the genre of fiction, extraordinary and supernatural events have been part of artistic creations in Nigerian literature. Fantasy and magic realism, which are past-oriented genres, have been conspicuously present. If we take the oral tradition as a precursor to written literature in Nigeria, it 
would be worth noting that many oral elements in Nigerian literature are fantastic in nature. The first set of Nigerian writers drew heavily on folkloric materials, which are largely fantastic in nature. D.O. Fagunwa's The Forest of a Thousand Daemons (1946) and Amos Tutuola's The Palm-Wine Drinkard (1952) are representative illustrations of this trend. Fagunwa, a Yoruba writer, draws from the abundant oral resources of the Yorubas in his writing and represents them in continuous prose. And Tutuola, a Nigerian writer who wrote in English, followed Fagunwa's tradition of focusing his creative lens on the imaginary world of the Yoruba folkloric tradition. Another Nigerian writer who has unreservedly deployed the fantastic in his oeuvre is poet and novelist Ben Okri. More recent than Tutuola and Fagunwa, Okri's artistry provides a more contemporary antecedent to Okorafor's narratives. Like Adichie, Okri believes in the productive, creative power of the story, and this is explicit in a statement he made during an interview with Charles Henry Rowell:

In its largest sense, story begins a process of laws, destinies, responsibilities, chaos. Story is a primeval thing. A story is not something that just happens to us as human beings. When lightning strikes the side of a mountain, and a rock breaks off, that is story. There is story in the wind, there is story in the rocks, in continents, in continental shifts. We can speak of the story of the universe and its birth of stars. We can speak of collision and fusion. Story is something bigger than us. We are part of it, we tap into it. Story is cosmological force. Story is a God. Story is huge. We really have to transfigure our sense of 
what story is. We are narrow in our perception of story, and we have lost its secret magnitude. The very fact of story means that you are demarcating something. You have a sense of an ideal, you have a sense of the way you wish things could or should be. This carries already within it a moral universe, a world framed with all kinds of dimensions and boundaries. You shape a world when you begin a story. (219; emphasis added) Within Okri's worldview, evident in the quotation above, there is no limit to what a story can do, and, in Okorafor's narratives, the power of storytelling is even more fully explored. Okorafor imbues her stories with unlimited possibilities, conscious of what Adichie calls "the danger of a single story" and aware of what Okri refers to as "the framing of a world through narratives" (219). Both the form and content of the two Okorafor novels under study here explore the unlimited power of the story to frame a world. These two novels represent strong, evocative forces in predicting the future by deliberately defamiliarizing our experiences of the Nigerian present while offering endless possibilities for the future.

\section{Magical Elements in What Sunny Saw in the Flames}

In What Sunny Saw in the Flames (published under the title Akata Witch outside of Nigeria and the United Kingdom), Okorafor writes the coming-of-age story of Sunny Nwazue, a thirteen-year old albino born in New York and living in Aba, Nigeria. Her American background, coupled with the pigmentation of her skin, makes her an easy target for ridicule by her classmates. From the onset of the novel, it is easy 
to perceive that Sunny has much to overcome in order to become a happy and fulfilled young woman. And Sunny's personal journey towards happiness and satisfaction is made even more difficult by the negative attitude towards albinos in Nigeria, which Jake Epelle, executive director of the Albino Foundation of Nigeria, sums up by itemizing the various derogatory terms used to describe albinos:

If you go into the names we are called you will just know that albinos have suffered untold derogatory insults. Let us take the Yoruba that call us Afin. Afin is not complimentary; it is derogatory. The Igbo call us Ayarin, the Edo people call us Ebo. Akwa Ibom people call us Bakara while the Hausa call us Bature Ntuda meaning "fake white man." (qtd. in Olagunju 51)

It is not only in naming that albinos suffer abuses, and their treatment can be linked to several myths surrounding the albino in Nigerian folklore. It is believed among the Yorubas and some other cultures that albinos are agents of the gods, sent to families that have offended the gods or the ancestors. Some believe that the blood of albinos is useful in money-making rituals and in fashioning charms for long life, while others believe that drinking the blood of a person with albinism bestows magical powers (Olagunju 50). Among all these misconceptions, to be a young albino in Nigeria is to possess a body that naturally depicts vulnerability and places the albino in the position of victim in society. In Okorafor's narrative, however, the albino rises above this stigmatized and misguided perception of her body through her discovery of her own magical powers, a departure 
from the start of the novel, when Sunny is shown to be a victim of her body and of her society in a way that she has internalized:

My name is Sunny Nkeiruka Nwazue and I confuse people . . . I'm Nigerian by blood, American by birth, and Nigerian again because I've lived here for years now ... . I have West African features, like my mother, but while the rest of my family is dark brown, I've got light yellow hair, skin the color of "sour milk" (or so stupid rude people like to tell me), and hazel eyes that look like God ran out of the right colour. I'm albino. (2) Seeing herself through the eyes of her society and comparing herself to other members of her family, Sunny describes herself in terms that suggest inadequacy. This negative perception has deep roots in the perceived natural weaknesses associated with being not only an albino but also a girl in Nigeria: "Being albino made the sun my enemy; my skin burned so easily that I felt nearly flammable. That's why, though I was really good at soccer, I couldn't join the boys when they played after school. Although they wouldn't have let me anyway, me being a girl" (2). Sunny also hints that her father hates her because she did not turn out to be a male child, nor is she "the pretty daughter he'd have accepted instead" (3). It seems, therefore, that Sunny must find a way to cope with her albinism, her gender, and her unfriendly classmates. When she does well on a class test and others get punished for their poor performances, Sunny becomes an easy target for their taunts. The following exchange is revealing:

"[D]id you like seeing that white woman beat us like that?

Does it make you happy because you're white, too?" 
"I'm not white!" Sunny shouted back in English . . . "I'm albino!"

"'Albino' is a synonym for 'ugly"' he retorted. (8; emphasis in original)

This conversation between Sunny and the boy called Periwinkle shows clearly the extent to which albinos are perceived negatively in Nigerian society. Albinism is not just synonymous with ugliness: it also suggests vulnerability, victimhood, and ostracism. In order to create a space of acceptance for this character, Okorafor creates a magical realm, one of friendship, where Sunny's weaknesses become her strength.

Exploring the myth of the Leopard People through Sunny's friendship with her friends Orlu and Chichi, Okorafor shows how modern Nigerian society can still remember and participate in ancestral cults. Sunny was born a Leopard Person, and she needs to discover this on her own, though she is helped by Orlu and Chichi, who are also Leopard People. Before each chapter, Okorafor provides short prologues that read like encyclopedic entries throwing light on what ensues in the following chapter. The prologue at the start of chapter four reads, "Now that you are a Leopard Person, know that your world has just become more real. Creatures are real. Ghosts, witches, demons, shape-shifters, and masquerades, all real.

Masquerades are always dangerous. They can kill, steal your soul, take your mind, take your past, rewrite your future, bring the end of the world, even" (39). Through her discovery of her identity as a Leopard Person, Sunny becomes more aware of the other realities 
apart from her lived, day-to-day reality in modern Ibo society. She also finds a space wherein her difference from others due to her skin colour is not only explicable but also important. It is within the context of the Leopard society that many of the magical events in the novel take place. Before her initiation, the reader has already encountered aspects of Sunny's magical nature through what she is able to see in fire. When she finds solace staring at a flickering candle flame, Sunny sees a vision of the end of the world, and this strange and curious vision is the novel's first recourse to a magical universe.

Leopard Knocks is presented in the novel as a magical place where anything can happen. It is here that Anatov and Sugar Cream, two mysterious scholars who are versed in the knowledge of the Leopard People, perform unbelievable rituals. It is also here that Sunny is initiated. Leopard Knocks can be reached via a mysterious narrow bridge described as "a 'link.' It's a patch of the spirit world that exists in the physical world. That's why Leopard Knocks was built here. Leopard Knocks is on an Island conjured up by the ancestors ... So, to cross you have to call up your spirit face" (41). Characters in the novel are thus shown as capable of shape-shifting, and this is what happens when they cross the bridge and call up their spirit faces. It is also magical that they spend strange money called Chittim, which they earn by learning the ways of the Leopard People. And Leopard People are presented in the novel as being able to use juju in order to do supernatural things. For example, Shasha, one of Sunny's friends, sends a masquerade - usually a person impersonating a spirit in an ancestral cult celebration - after three 
boys in his class for insulting his parents, and two of the boys are "mentally messed up" as a result (37). Sunny thus comes to realize the strengths of a Leopard Person.

Explaining to Sunny her initiation into the Leopard community, Anatov, who is a kind of priest, instructs her to "[i]magine that you are a computer that came with programs and applications already installed. In order to use them, they have to be activated; you have to, in a sense wake it up. That's what initiation is" (33). What Okorafor succeeds in doing in this exchange (and in several other episodes in the novel) is to juxtapose mythical and traditional worldviews and events with modern references and occurrences. She uses the twenty-first century reality of the computer to explicate the workings of age-old traditional practices in order to show the positioning of these traditional worldviews and beliefs within present realities. Anatov, a custodian of traditional values, is described as having an American accent but also speaks flawless Ibo. Okorafor's critical point here is that it is possible for an individual - and, by extension, a community - to reach both extremes of the spectrum, to encompass the values of both traditional African culture and western civilization.

Sunny's visions begin when the electricity supply is cut temporarily, a common occurrence in Nigeria. She peers into the flames and sees the end of the world, and this is a vision that Okorafor associates with the hallmarks of Sunny's characterization: visibility and invisibility, possibility and impossibility, traditional Nigerian values and the influences of western culture - all coalescing 
in what appears to be not just the Nigerian present but also its future. At the end of her initiation, Sunny returns home and is surprised that things are still the same at school: "Once the teacher started talking, Sunny was surprised that she was still interested in learning normal things like algebra, literature, and biology. She could still concentrate" (217). Thus, Okorafor enlivens myth in this coming-of-age fiction. Using the myth of the Leopard People, she imbues her albino protagonist with special powers that she and her friends later use to help capturing a kidnapper named Black Hat Otokoto.

\section{African Science Fiction in Lagoon}

In Lagoon, a more recent work, Okorafor mixes elements of Nigerian culture with science fiction. Drawing on the common science fiction trope of alien invasion, she considers the possible effects of an alien invasion on Lagos, a Nigerian coastal city of eighteen million people. Lagoon continues a long tradition of writings centered on Nigeria's commercial capital, but it does so in a very distinctive way. Abandoning the realistic vision of Lagos depicted in novels such as Sefi Atta's Everything Good Will Come (2005) and Chris Abani's GraceLand (2004) -both authors contemporaries of Okorafor Lagoon depicts a futuristic vision of the city that situates the novel in the realm of science fiction. Okorafor takes a step further than she did in What Sunny Saw in the Flames by blending magical elements with science fiction and including the unsettling possibility of alien invasion. 
James Gunn, a noted science fiction writer and scholar, theorizes the genre of science fiction with recourse to its temporality and its representation of large-scale social change:

Science fiction is the branch of literature that deals with the effects of change on people in the real world as it can be projected into the past, the future, or to distant places. It often concerns itself with scientific or technological change, and it usually involves matters whose importance is greater than the individual or the community; often civilization or the race itself is in danger. (73-74)

Using multiple points of view, Okorafor is able to show the possible effects of an alien invasion on different individuals in Nigerian society. It is worth noting that Lagoon is not merely a novel about Lagos but an experience of Lagos. Like the waters of Lagos to which the novel so frequently alludes, Lagoon bustles with creatures, people, and animals who are all actively involved in the narrative; indeed, Lagoon is another name for Lagos. Reading the novel, then, is like being submerged in the waters, baptized into Okorafor's spirited crosscurrent of emotions. Filled with memories and allusions to historical figures and events, the novel transcends our limited views of reality or of science fiction itself. This is because Okorafor problematizes the very genre of science fiction by setting her novel in Lagos and forcing the city to welcome aliens among the already existing supernatural beings in Africa. One is left with no choice but to fashion new ways of describing the experience, at once uniquely African and futuristic. The more Lagoon resists definition, the more attention it focuses on the 
shores of Bar Beach and Tin Can Island, and the more we become aware of the Afrocentric nature of the novel's concerns. Even in the very western idea of alien invasion, the novel depicts a baptismal rite of naming that renders the experience something more than just the reiteration of a western trope: the aliens take on Nigerian names and become Nigerians.

At the onset of the narrative, we meet Adaora, a marine biologist; Anthony, a famous Ghanaian rapper; and Agu, a Nigerian soldier on the run. The three are assembled at Bar Beach, described by the narrator as "a perfect sample of Nigerian society . . . a place of mixing" (7), thus functioning as a microcosm for Lagos. Using Lagos as the setting for this invasion affords Okorafor the opportunity to covertly critique the disorderliness of present-day Nigeria, which would make it difficult to detect an alien invasion in the first place: "Adaora was beginning to see why Ayodele's people had chosen the city of Lagos. If they'd landed in New York, Tokyo, or London, the governments of these places would have swooped in to hide, isolate, and study the aliens. Here in Lagos, there was no such order" (64). Okorafor's narrative choice highlights science fiction's potential for social critique of the present day while simultaneously drawing attention to how mishandled social ills might manifest greater harms in the envisioned Nigerian future.

The novel's Nigerian characters react to the invasion in markedly different ways. Adaora, the marine biologist, immediately makes the aliens' representative (to whom she gives the name Ayodele) a specimen in her laboratory. This is perhaps the most justifiable 
interest that a human being can have in the aliens. In the lab, it is discovered that Ayodele's skin is made up of several iron balls, which explains her ability to change into anything she wishes: a lizard, an old woman, and even a replica of Adaora's husband, Chris. For many other Nigerians, however, the alien invasion is seen as an opportunity for selfish gain. When Philo, Adaora's housekeeper, notifies her boyfriend, Moziz, about Ayodele, he in turn notifies his friends, and they plan to kidnap Ayodele in order to ransom her for money. To them, the alien's shape-shifting capabilities present an opportunity for monetary gain. Father Oke, too, presented in the novel as a domineering man of God, tries to manipulate the aliens into joining his congregation. Having publicly slapped a woman he accuses of being a witch, Father Oke's nemesis is revealed when he tries to manipulate the crowd in front of Ayodele's house. In the ensuing backlash, he faces a barrage of insults and is slapped before being led away by a woman appearing to be Mammy Water, a river goddess and the leader of marine witches. But the aliens' arrival instantiates other changes, too: for instance, a transgender group called Black Nexus gains the courage to appear in public without any attempt to disguise who they are.

It is remarkable that Ayodele and her people choose Lagos as the site of their integration into the future on Earth. What is unique about this envisioning of the future is that it is woven with the threads of the past and the present, validating the claim that African authors cannot cite dissatisfaction or disillusionment with the past as the sole force for the emergence of what we call Afro-science fiction. 
Okorafor, in this story, brings to life a fascinating view of Lagos in all its contradictions. The alien invasion in Lagoon merely amplifies aspects of the city's chaos, showing with only marginal distortion Lagos's chaotic and volatile nature. The aliens, Okorafor means us to realize, are not the problem: the novel emphasizes instead the vices already present in the everyday lives of ordinary Lagosians. The major thematic preoccupation in the novel is the possible effect of an alien invasion on the common Lagosian, on the animals and insects that live in the city. Okorafor tells a story about humanity at the crossroads between the past, present, and future as Lagoon meanders through political and philosophical issues in the rich tradition of science fiction. It is a portrayal of Lagos's chaotic activities, but it is a portrait, too, of Nigerian society as a whole; it illuminates a range of narrative themes broad enough to encompass gender relations, post-colonialism, the dangers of prejudice, questions of nationalism and patriotism, history and ancestry, freedom, and hope for a positive future.

Nowhere else is the positive effect of the alien invasion in Lagoon felt so acutely as in the healing and rebirth of the ailing Nigerian president. Flown into the country on the verge of death, he encounters Ayodele, who, through her magical powers, heals him. But she does not heal his body alone: she also heals his mind. When he returns to Lagos after being led into the waters to meet the alien elders, he addresses his fellow Nigerian citizens with a renewed strength and sense of focus: 
The president had never been a great orator. But today, this early evening, he was feeling his words. He was tasting them. They were humming to the rhythm of his soul. He smiled as he spoke. "For the first time since we cast off the shackles of colonialism, over a half century ago, since we rolled through decades of corruption and internal struggle, we have reached the tipping point. And here in Lagos, we have passed it. Many of you have seen the footage on the Internet or heard the news from loved ones. Last night, Lagos burned. But like a phoenix, it will rise from the ashes - a greater creature than ever before ... This shift is cause for celebration not panic ... There are others among us here in Lagos. They intend to stay. And I am happy about it. They have new technology; they have fresh ideas that we can combine with our own." (276)

It is on this positive note that the human aspect of the novel comes to an end, but the story does not end, however, with human activity alone. Unsurprising for a novel that gives as much narrative attention to a bat and a tarantula as it does to the Nigerian president, Lagoon ends with Udide Okwanka, a folkloric spider upon whom Okorafor bestows the credit of telling the story.

\section{Conclusion}

As made evident throughout this paper, both Lagoon and What Sunny Saw in the Flames thrive on Nigerian magical elements. In the latter, Okorafor employs the myth of Leopard People to counter mythical 
stereotypes associated with albinism in Nigeria. She imbues her albino character with magical powers that help her rise above the denigrating stereotypes associated with the colour of her skin. She also overcomes her sense of helplessness by using her magical powers in the search for Black Hat Otokoto, a kidnapper of children. This magical world's co-existence with the normal, everyday realities of school and family life suggests that, beneath the surface of modern existence in Nigeria, there are other magical realities that are not obvious to all. This magical reality coincides with an alien invasion in Lagoon, imbuing a science fiction novel - a relatively phenomenon in Nigerian literature - with a distinctive African flavor. Okorafor thus introduces new possibilities into Nigerian fiction, demonstrating its capacity to appropriate western modes and tropes while simultaneously retaining and respecting traditional African ideas. Introducing a phenomenon like alien invasion into the corpus of Nigerian fiction does not radically distort existing styles: rather, this integration seems to provide a better springboard for the novel as a means of social critique. Within the endless possibilities introduced into this style of storytelling, an Afro-science fiction emerges, presenting Nigeria as a perfect setting for welcoming earthly integration. 0

\section{Works Cited}

Achebe, Chinua. Anthills of the Savannah. London: Heinemann, 1987. Print. 
---. "The Novelist as a Teacher." Hopes and Impediments: Selected Essays. New York: Doubleday, 1990. 40-46. Print.

Adichie, Chimamanda Ngozi. "The Danger of a Single Story." TED. July 2009. Lecture.

Byrne, Deirdre C. "Science Fiction in South Africa." PMLA 119.3 (2004): 522-25. Print.

Fagunwa, D.O. The Forest of a Thousand Daemons. Trans. Wole Soyinka. Lagos: Nelson, 1982. Print.

Gunn, James. The Science of Science-Fiction Writing. Lanham:

Scarecrow, 2003. Print.

Okorafor, Nnedi. What Sunny Saw in the Flames. Ibadan: Cassava,

2011. Print.

---. Lagoon. London: Hodder and Stoughton, 2014. Print.

Okri, Ben. Interview by Charles Henry Rowell. Callaloo 37.2 (2014): 214-21. Print.

Olagunju, Olugbenga Samuel. "Towards a Biblical Response to Myth and Discrimination against the Human Right of Albinos in Yorubaland." Journal of Studies in Social Sciences 1.1 (2012): 4658. Print.

Onifade, Hannah. "Exclusive Interview with Nigerian Science Fiction Author Nnedi Okorafor." Ventures Africa. Ventures Africa, 23 Sept. 2015. Web. 8 Aug. 2016.

Milner, Andrew. "Science Fiction and the Literary Field." Science Fiction Studies 38.3 (2011): 393-411. Print.

Tutuola, Amos. The Palm-Wine Drinkard. Ibadan: Spectrum, 1963.

Print. 
Mary Bosede Aiyetoro just concluded her doctoral research in the Department of English at the University of Ibadan. She currently teaches English and African Literature in the Department of English at Bowen University in Iwo, Nigeria. Her research interests are publishing and new Nigerian writing.

Elizabeth Olubukola Olaoye has taught at Ajayi Crowther University in Oyo, Nigeria, and she has published in several reputable journals within and outside Nigeria. Her research interests are African literature, fantasy, and literature and gender.

Return to contents (LINK) 